\title{
Synthesis and Characterization of a Novel
}

\section{Biheterocyclic $\alpha$-amino Acid Precursor of the Triazole- Tetrazole Type, via the Copper (I) Catalyzed Alkyne- Azide Cycloaddition Reaction (CuAAC)}

\author{
Khadim Dioukhane, Younas Aouine, Salaheddine Boukhssas, Asmae Nakkabi, Hassane Faraj, and
} Anouar Alami

\section{ABSTRACT}

In this paper, we describe the regioselective synthesis of a novel triheterocyclic compound, a biheterocyclic amino acid precursor, derived from both triazole and tetrazole. The key step of our synthesis approach was the Huigsen 1,3-dipolar cycloaddition reaction, catalyzed by the copper (I) formed in situ by reduction of $\mathrm{Cu}(\mathrm{II})$ salts $\left.\left(\mathrm{CuSO}_{4}\right), 5 \mathrm{H}_{2} \mathrm{O}\right)$ by sodium ascorbate, and using as dipole the oxazoline azide derivative 4(azidomethyl)-4-ethyl-2-phenyl-4,5-dihydrooxazole (4) and as dipolarophile 5-(4-methoxyphenyl)-2-(prop-2-yn-1-yl)-2H-tetrazole (3). The $\mathrm{Cu}(\mathrm{I})$ catalysis allowed us to carry out the cycloaddition at room temperature during a reaction time of only 8 hours and also to selectively obtain the 1,4-regioisomer; one of the two possible isomers, with a yield of $90 \%$ after chromatography on a silica gel column (ether/hexane: 1/2), and recrystallization in an ether/acetone mixture. The desired compound, 4ethyl-4-((4-((5-(4-methoxyphenyl)-2H-tetrazol-2-yl)methyl)-1H-1,2,3triazol-1-yl)methyl)-2-phenyl-4,5-dihydrooxazole (5) was analyzed by 1D magnetic resonance spectroscopy $\left({ }^{1} \mathrm{H},{ }^{13} \mathrm{C}\right)$, and characterized physicochemically by mass spectrometry and elemental analysis.

Keywords: Tetrazole, alkyne, oxazoline azide, Triazole, CuAAC.

Published Online: March 26, 2021

ISSN: $2684-4478$

DOI : 10.24018/ejchem.2021.2.2.53

Khadim Dioukhane

Engineering Laboratory of Organometallic, Molecular Materials and Environment (LIMOME), Faculty of Sciences Dhar El Mahraz, Sidi Mohammed Ben Abdellah University, Morocco.

(e-mail: dioukhanekhadim@ ${ }^{\circledR m a i l . c o m) ~}$ Younas Aouine

Team of Organic Chemistry and Valorization of Natural Substances (COVSN), Faculty of Sciences, Ibn Zohr University, Morocco.

(e-mail: y.aouine@uiz.ac.ma)

Salaheddine Boukhssas

Engineering Laboratory of

Organometallic, Molecular Materials and Environment (LIMOME), Faculty of Sciences Dhar El Mahraz, Sidi Mohammed Ben Abdellah University, Morocco.

(e-mail: salah.boukhssas @gmail.com) Amae Nakkabi

Laboratory of Chemistry of Materials and Biotechnology of Natural Products, Faculty of Sciences, Moulay Ismail University, Morocco.

(e-mail: asmaenakkabi@ ${ }^{\mathrm{yahoo} . f r)}$

Hassane Faraj

Engineering Laboratory of Organometallic, Molecular Materials and Environment (LIMOME), Faculty of Sciences Dhar El Mahraz, Sidi Mohammed Ben Abdellah University, Morocco.

(e-mail: anouar.alami ${ }^{@}$ usmba.ac.ma) Anouar Alami *

Engineering Laboratory of

Organometallic, Molecular Materials and Environment (LIMOME), Faculty of Sciences Dhar El Mahraz, Sidi Mohammed Ben Abdellah University, Morocco

(e-mail: hassanefaraj@yahoo.fr)

*Corresponding Author 


\section{INTRODUCTION}

Tetrazole derivatives have been of great interest in recent years because of their potential pharmacological properties [1]]-[10]. They can act as bioisosters of the carboxylate group [11], since they have a similar $\mathrm{pKa}$ and are deprotonated at physiological $\mathrm{pH}$. This characteristic enables them to resist metabolic degradation. For example, Losartan and Candesartan are two angiotensin II receptor antagonists. These compounds show better binding affinity and action when administered orally. The increased binding strength to the receptor is due to the high capacity of tetrazole to distribute a negative charge at physiological $\mathrm{pH}$, allowing for better interaction with the positive charge at the receptor [12]. Thus, the major advantage of tetrazoles over carboxylic acids is that they resist several biological processes of metabolic degradation. Benzoic acid derivatives often undergo the formation of covalent bonds with the transferred enzymes to form activated species. The same activation process does not occur with aromatic or aliphatic tetrazoles.

Due to the extensive applications of tetrazole derivatives, much effort has been devoted to the development of various preparation methods for the establishment of many tetrazole derivatives [13], [14]. Of these, the cyclocharge reaction $[3+2]$ between nitriles or oximes and an azide source is the most commonly used procedure for accessing 5-substituted tetrazole derivatives. In the light of these observations and in the continuity of our previous work on the synthesis of 2,5disubstituted tetrazolic compounds [15]-[18], we have focused in this work on the regioselective synthesis of 5-(4methoxyphenyl)-2-(prop-2-yn-1-yl)-2H-tetrazole (3), which will subsequently be used as a dipolarophile in a $\mathrm{Cu}(\mathrm{I})$ - catalyzed cycloaddition reaction with the dipole 4(azidomethyl)-4-ethyl-2-phenyl-4,5-dihydrooxazole (4). Indeed, in our laboratory, starting from 4-methyl-2phenyloxazoline, EL HAJJI [19] has developed a method of preparation of precursor triheterocyclic systems of $\alpha$-amino acids and $\alpha$-amino aldehydes by action of certain acetylenic derivatives on various azides. ZAID [20], for his part, took up and continued this work and obtained new triheterocyclic systems, which enabled him to eventually develop $\alpha$-amino aldehydes and bitriazolic $\alpha$-amino acids. For our part, starting from the same starting synthon, we report in this paper the synthesis of a new tri-heterocyclic compound, a biheterocyclic $\alpha$-amino acid precursor of the triazoletetrazole. The key step in our synthesis strategy (Scheme 1), was the Huigsen 1,3-dipolar cycloadditiion reaction between the oxazoline azide derivative (4) and the 5-(4methoxyphenyl)-2-(prop-2-yn-1-yl)-2H-tetrazole (3). This is catalyzed by copper (I) formed in situ by reduction of $\mathrm{Cu}$ (II) salts $\left(\mathrm{CuSO}_{4}, 5 \mathrm{H}_{2} \mathrm{O}\right)$ by sodium ascorbate in a water-ethanol solvent mixture (1/1). $\mathrm{Cu}(\mathrm{I})$ catalysis allowed us to carry out the cycloaddition at room temperature during a reaction time of only 8 hours and also to selectively obtain the triazole 1,4regioisomer; one of the two possible isomers, with a yield of $90 \%$ after chromatography on silica gel column (ether/hexane: 1/2), and recrystallization in an ether/acetone mixture. The triheterocyclic compound (5) is obtained pure with an excellent yield. Its structure has been established on the basis of NMR spectroscopy $\left({ }^{1} \mathrm{H},{ }^{13} \mathrm{C}\right)$, mass spectrometry and elemental analysis.

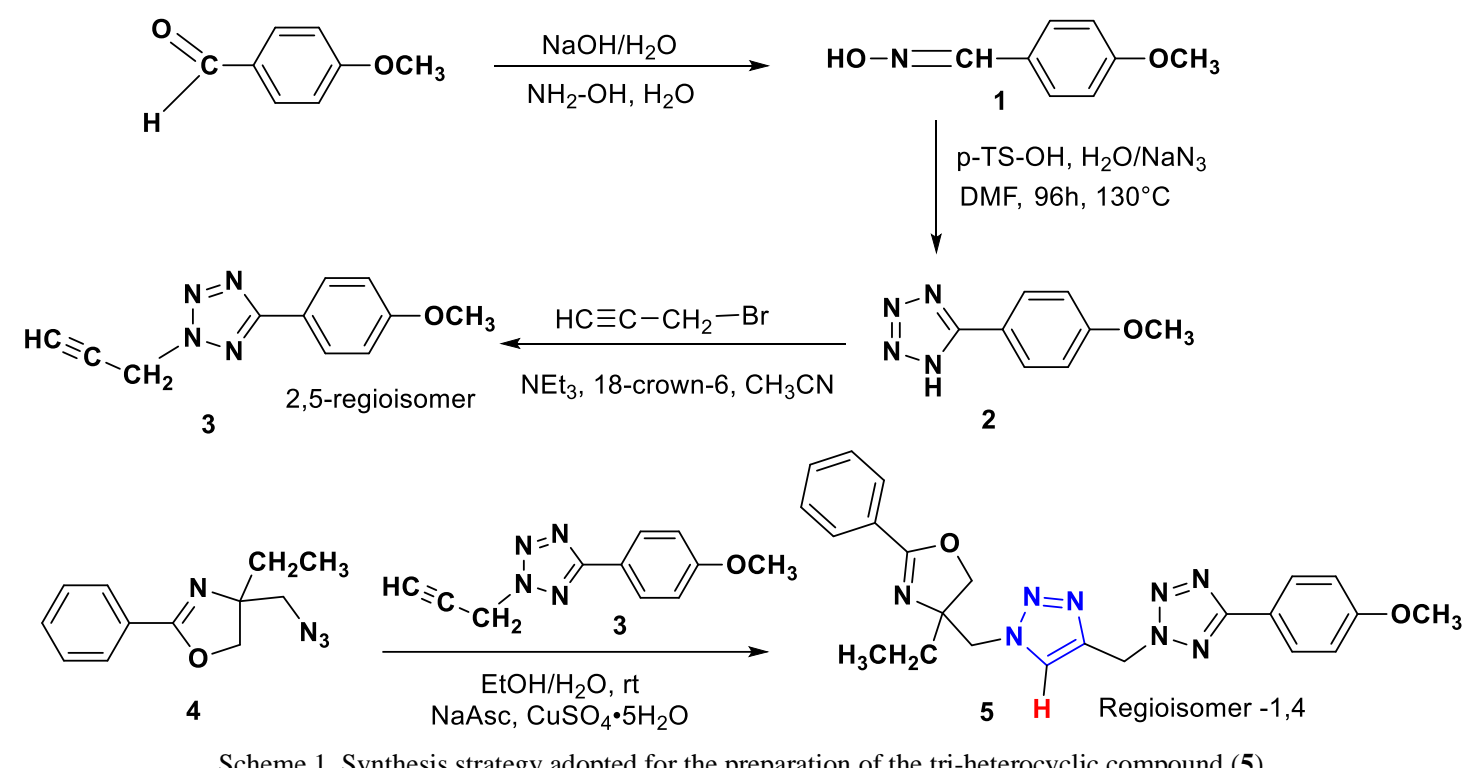

\section{RESULTS AND DISCUSSION}

The azide compound, 4-(azidomethyl)-4-ethyl-2-phenyl4,5-dihydrooxazole (4) is prepared from the commercial product, 2-amino-2-methyl propan-1,3-diol (CAS No. [11569-5]) according to the same reaction protocol adopted by EL HAJJI [22] and HAJIB [23].

The synthesis of tetrazolic alkyne first requires the preparation of 5-(4-methoxyphenyl)- $1 H$-tetrazole. Thus, for its preparation, we based ourselves on the method described by LIPPMANN and KÖNNECKE [24] and taken up in our laboratory by ALAMI [15] then by ACHAMALE [17] using aldoxime as starting material. This method consists first of preparing the tosylated oxime salt, which is then transformed into the corresponding nitrile. The latter is used as a dipolarophile in a cycloaddition reaction in the presence of sodium azide as a dipole. Thus, for the preparation of 5-(4methoxyphenyl)-1H-tetrazole (2), we have preferred to use a 
monotope or one-pot synthesis. This is a chemical synthesis in which a reagent undergoes several successive reactions in a single reaction mixture. It thus avoids long separation and purification processes of intermediate compounds. This type of reaction is actively sought after by chemists because it allows them to save time and increase the overall chemical yield. The process by which a multi-step synthesis is reduced to a single-step synthesis is called telescoping. Thus, the tosylated oxime salt and nitrile are prepared "in situ" in the same cycloaddition reaction with sodium azide, starting with an oxime as starting material (Scheme 2).

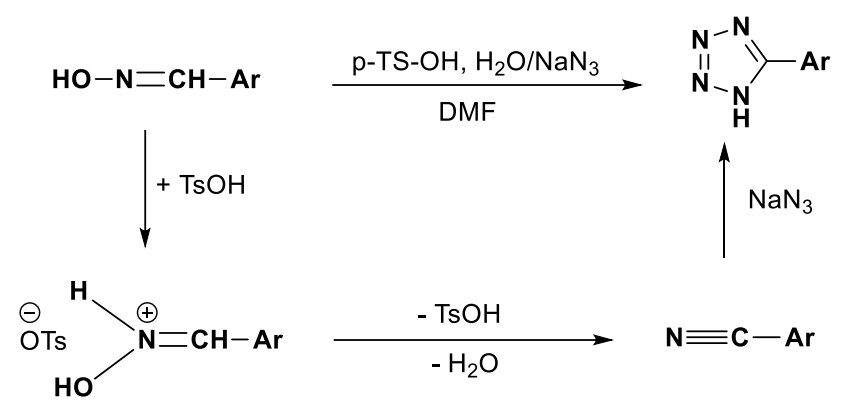

Scheme 2. Reaction protocol for the synthesis of 5-substituted tetrazoles.

Thus, commercially available 4-methoxy benzaldehyde oxime (CAS No. [3717-22-4]) was prepared in our laboratory with a yield of $89 \%$ from commercially available 4methoxybenzaldehyde (CAS No. [123-11-5]). The reaction is carried out in an aqueous medium in the presence of sodium hydroxide and hydroxylamine hydrochloride (Scheme 3 ).

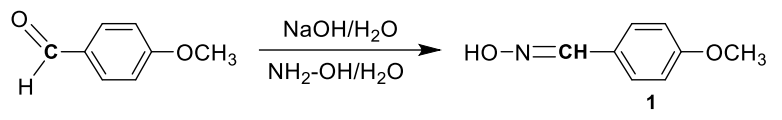

Scheme 3. Oxime synthesis route (1).

The isolated oxime (1) was characterised by 1D NMR of proton and carbon 13 (Fig, 1 and 2) and by comparison with data from the literature. Thus, its proton NMR spectrum shows the following signals:

- A singlet around $3.84 \mathrm{ppm}$ corresponding to the 3 protons of the methoxy group $-\mathrm{OCH}_{3}$.

- A doublet split around $6.93 \mathrm{ppm}$ corresponding to the 2 aromatic protons $\left(J_{1}=6.9 \mathrm{~Hz}\right.$ and $\left.J_{2}=2.1 \mathrm{~Hz}\right)$.

- A doublet split to $7.55 \mathrm{ppm}$ corresponding to the 2 aromatic protons $\left(J_{1}=6.9 \mathrm{~Hz}\right.$ and $\left.J_{2}=2.1 \mathrm{~Hz}\right)$.

- A singlet around $8.17 \mathrm{ppm}$ corresponding to the proton $\mathrm{CH}=\mathrm{N}-$.

- A signal widened to $9.42 \mathrm{ppm}$ corresponding to the hydroxyl proton $-\mathrm{OH}$.

As for its ${ }^{13} \mathrm{C}$ NMR spectrum, it is characterized by the following signals (Fig. 2.):

- A signal around $55.35 \mathrm{ppm}$ corresponding to the carbon of the methoxy group $-\mathrm{OCH}_{3}$.

- An intense signal around $114.31 \mathrm{ppm}$ corresponding to the 2 aromatic carbons.

- A signal around $124.56 \mathrm{ppm}$ corresponding to the quaternary aromatic carbon bound to $-\mathrm{CH}=\mathrm{N}-\mathrm{OH}$.

- An intense signal around $128.63 \mathrm{ppm}$ corresponding to the 2 aromatic carbons.

- A signal around $150.03 \mathrm{ppm}$ corresponding to carbon $\mathrm{CH}=\mathrm{N}-\mathrm{OH}$.
- A signal around $161.10 \mathrm{ppm}$ corresponding to the quaternary aromatic carbon linked to the methoxy group.

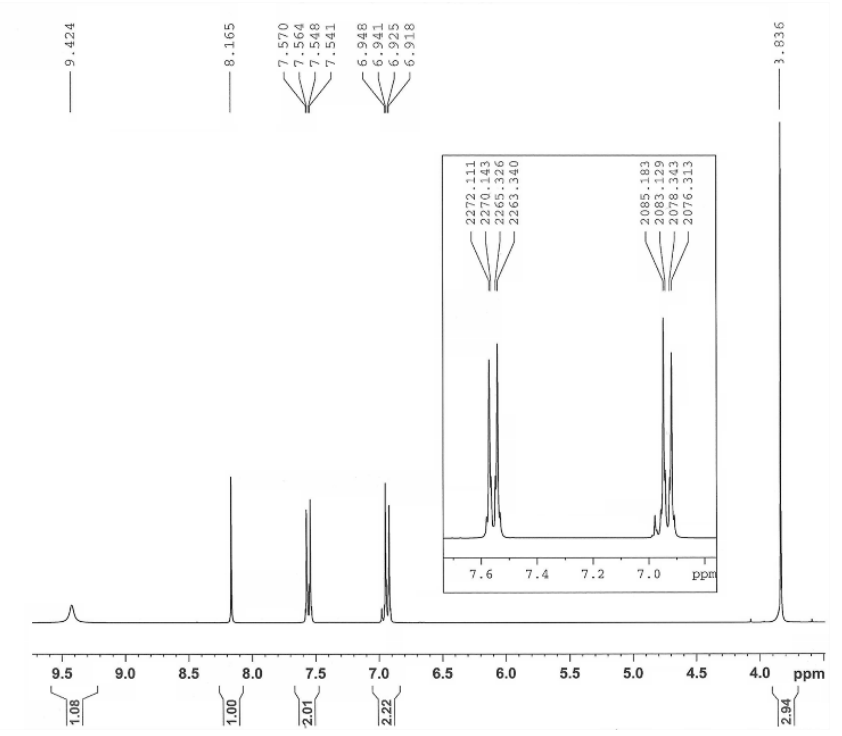

Fig. 1. ${ }^{1} \mathrm{H}-\mathrm{NMR}$ 1D spectrum of compound (1)

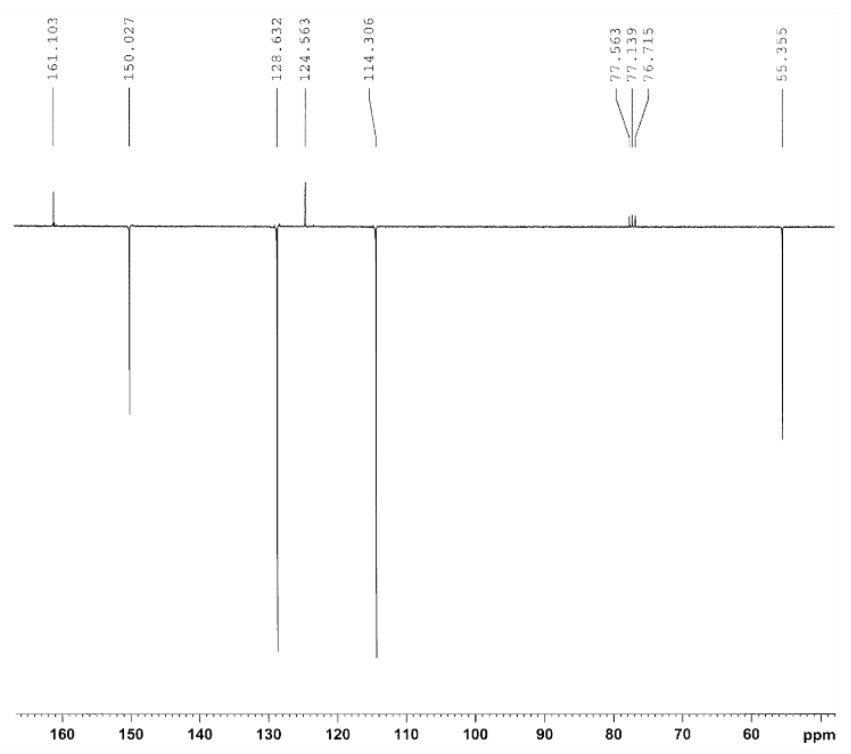

Fig. $2 .{ }^{13} \mathrm{C}-\mathrm{NMR}$ 1D spectrum of compound (1).

The oxime thus obtained was transformed in a single step into tetrazole by the action of sodium azide in the presence of paratoluenesulfonic acid monohydrate in $N, N$ dimethylformamide (DMF) (Scheme 4). The reaction mixture was stirred for 96 hours at $130{ }^{\circ} \mathrm{C}$.<smiles>COc1ccc(/C=N/O)cc1</smiles>

Scheme 4. Synthesis route of 5-(4-methoxyphenyl)tetrazole (2).

5-(4-methoxyphenyl)tetrazole (2) was obtained pure after recrystallisation in ethyl acetate with a yield of $75 \%$. It has been identified on the basis of the analysis of its ${ }^{1} \mathrm{H}$ and ${ }^{13} \mathrm{C}$ 1D NMR spectra and by comparison with data from the literature [24], [15]. Thus, its ${ }^{1} \mathrm{H}$ NMR spectrum (Fig. 3) shows the following signals: 
- A singlet around $3.83 \mathrm{ppm}$ corresponding to the 3 protons of the methoxy group $-\mathrm{OCH}_{3}$.

- A doublet around 7.14 ppm corresponding to the two 2 aromatic protons $(J=8.8 \mathrm{~Hz})$.

- A doublet around $7.98 \mathrm{ppm}$ corresponding to the two 2 aromatic protons $(J=8.8 \mathrm{~Hz})$.

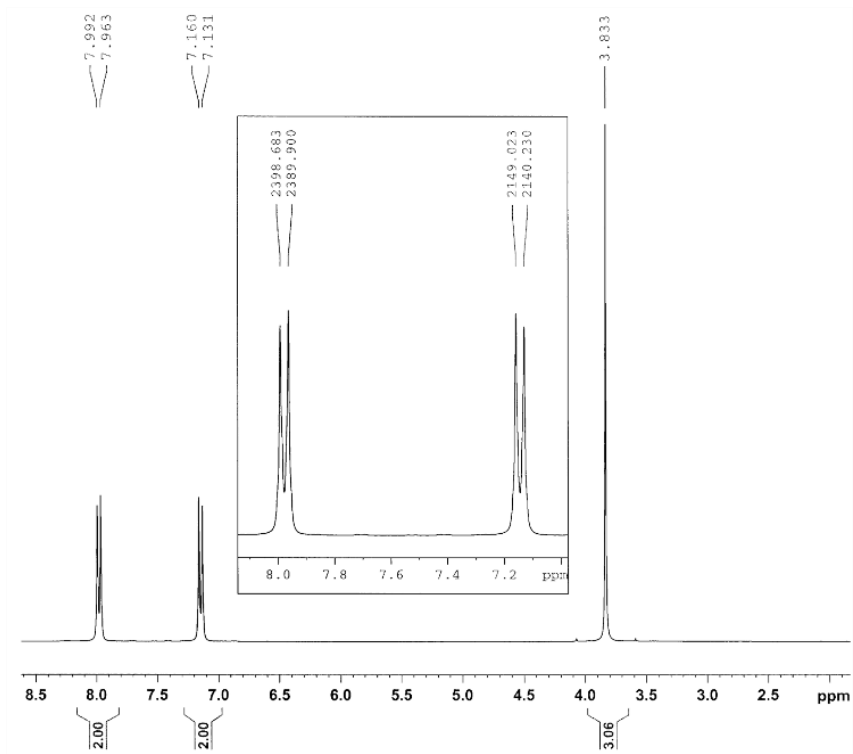

Fig. 3. ${ }^{1} \mathrm{H}-\mathrm{NMR}$ 1D spectrum of compound (2).

Its ${ }^{13} \mathrm{C}$ NMR spectrum (Fig. 4) also shows the following signals:

- A signal around $55.87 \mathrm{ppm}$ corresponding to the carbon of the methoxy group $-\mathrm{OCH}_{3}$.

- An intense signal around $115.27 \mathrm{ppm}$ corresponding to the 2 aromatic carbons.

- A signal around $116.73 \mathrm{ppm}$ corresponding to the quaternary aromatic carbon linked to the tetrazole ring.

- An intense signal around 129.08 ppm corresponding to the 2 aromatic carbons.

- A signal around $150.03 \mathrm{ppm}$ corresponding to the carbon of the tetrazole cycle.

- A signal around $161.91 \mathrm{ppm}$ corresponding to the quaternary aromatic carbon linked to the methoxy group.

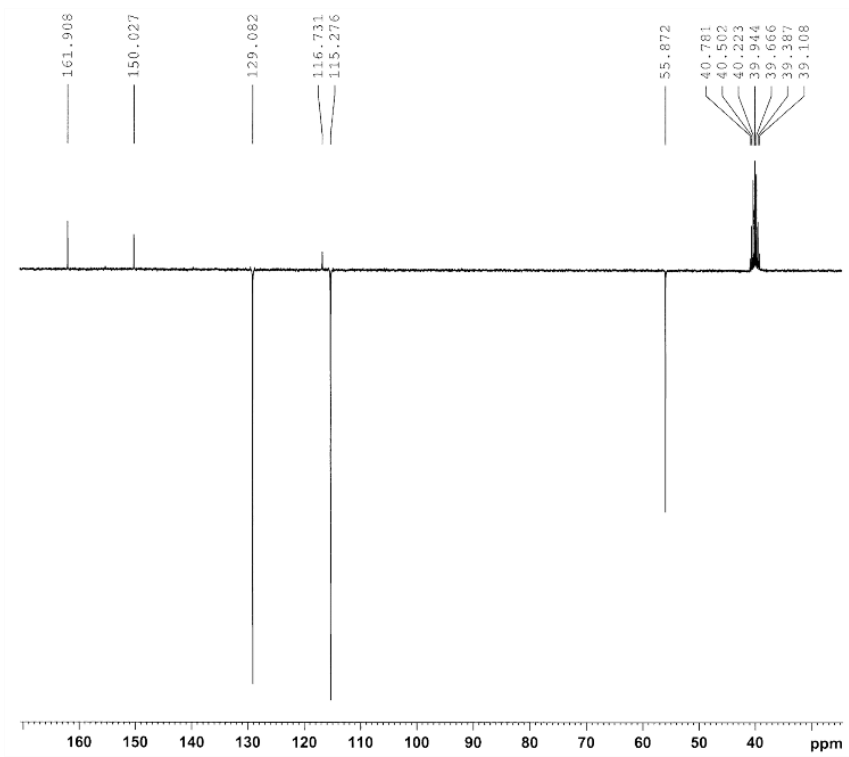

Fig. 4. ${ }^{13}$ C-NMR 1D spectrum of compound (2).

The action of 5-substituted tetrazole on propargyl bromide is carried out in acetonirtrile in the presence of triethylamine and 18 -crown-6 in catalytic quantity, at room temperature for 4 hours (Scheme 5). Only the 2,5-disubstituted tetrazole regioisomer is isolated pure after chromatography on a silica gel column (ether/petroleum ether (20/80)) with a yield of $85 \%$. The 18 -crown- 6 ether is used to promote nucleophilic substitution by preventing the pairing of ions, which act as naked nucleophiles.

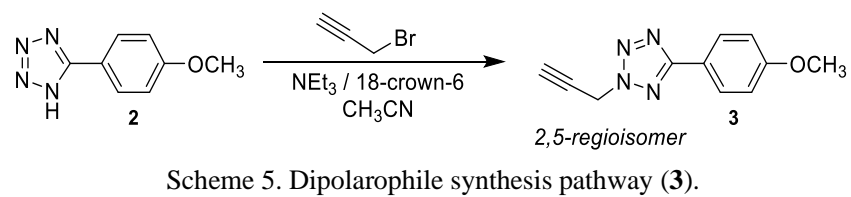

The structure of the dipolarophile has been confirmed, in addition to ${ }^{1} \mathrm{H}$ and 2D HSQC NMR, by mass spectrometry $\left(\mathrm{DCI} / \mathrm{NH}_{3}\right)$, by weight analysis, and taking into account the data in the literature concerning the orientation of the $\mathrm{N}$ alkylation of the 5-substituted tetrazole. 5-substituted tetrazoles are characterized by the presence of an acidic proton, which can occupy two different positions in the heterocycle [8] according to the following tautomeric equilibrium (Scheme 6).<smiles>[Al]c1nnn[nH]1</smiles>

$1 H$-Form<smiles>[Al]c1nn[nH]n1</smiles>

$2 \mathrm{H}$-Form

Scheme 6. Tautomerism of tetrazole derivatives.

We can therefore expect to obtain two regioisomers during alkylation reactions where the tetrazole will play the role of a nucleophilic entity. According to data from the literature [25]-[29], the N-alkylation of tetrazole substituted in the 5position by alkyl, aryl, sulphonic ester or ester groups [25], leads to the formation of two regioisomers 1,5- and 2,5(Scheme 7).
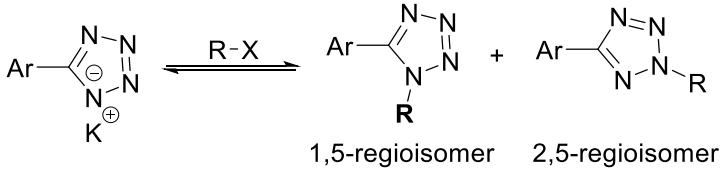

Scheme 7. $N$-alkylation reaction of 5-aryl-tetrazole.

The regioselectivity of the $N$-alkylation of 5-substituted tetrazole is strongly dependent on the electronic structure of the substituent carried by the carbon atom [26]. In the majority of cases of alkylation of tetrazoles substituted in position 5 by an attracting group, the 2,5-regioisomer [27][29] was obtained in the majority of cases. In the case of nitrotetrazole only the 2,5-regioisomer is obtained. On the other hand, the use of tetrazoles [30], unsubstituted or substituted by an electron-donating group, preferentially leads to the formation of the 1,5-regioisomer. Moreover, concerning ${ }^{13} \mathrm{C} \mathrm{NMR}$, the literature [31]-[33] reports that the chemical shift of the carbon in position 5 of the aromaticsubstituted tetrazole derived from benzene $\left(-\mathrm{C}_{6} \mathrm{H}_{5}, \mathrm{p}-\mathrm{Me}-\right.$ 
$\left.\mathrm{C}_{6} \mathrm{H}_{4}, \mathrm{p}-\mathrm{MeO}-\mathrm{C}_{6} \mathrm{H}_{4}, \mathrm{p}-\mathrm{Cl}-\mathrm{C}_{6} \mathrm{H}_{4}, \mathrm{p}-\mathrm{Br}-\mathrm{C}_{6} \mathrm{H}_{4}, \mathrm{p}-\mathrm{NO}_{2}-\mathrm{C}_{6} \mathrm{H}_{4} \ldots\right)$ is more deflected in the 2,5-regioisomer than in its homologous 1,5-regioisomer. All of these findings were of great use in attributing the structure of the 2,5-regioisomer to the substitute, considering that alkylation of the tetrazolate anion takes place on the 2 nitrogen atom of the tetrazolic nucleus.

The ${ }^{1} \mathrm{H}$ NMR spectrum of the of 5-(4-methoxyphenyl)-2(prop-2-yn-1-yl)-2H-tetrazole (3) shows the following signals (Fig. 5):

- A triplet around $3.23 \mathrm{ppm}$ corresponding to the acetylenic proton $-\mathrm{C} \equiv \mathrm{CH}(J=2.62 \mathrm{~Hz})$.

- A singlet around $3.89 \mathrm{ppm}$ corresponding to the 3 protons of the methoxy group $-\mathrm{OCH}_{3}$.

- A doublet around $5.68 \mathrm{ppm}$ corresponding to the 2 protons of methylene $-\mathrm{CH}_{2}-\mathrm{C} \equiv \mathrm{CH}(J=2.62 \mathrm{~Hz})$.

- A doublet split to $7.11 \mathrm{ppm}$ corresponding to the 2 aromatic protons $\left(J_{1}=6.8 \mathrm{~Hz}\right.$ and $\left.J_{2}=2.2 \mathrm{~Hz}\right)$.

- A doublet split around $8.08 \mathrm{ppm}$ corresponding to the 2 aromatic protons $\left(J_{1}=6.8 \mathrm{~Hz}\right.$ and $\left.J_{2}=2.2 \mathrm{~Hz}\right)$.

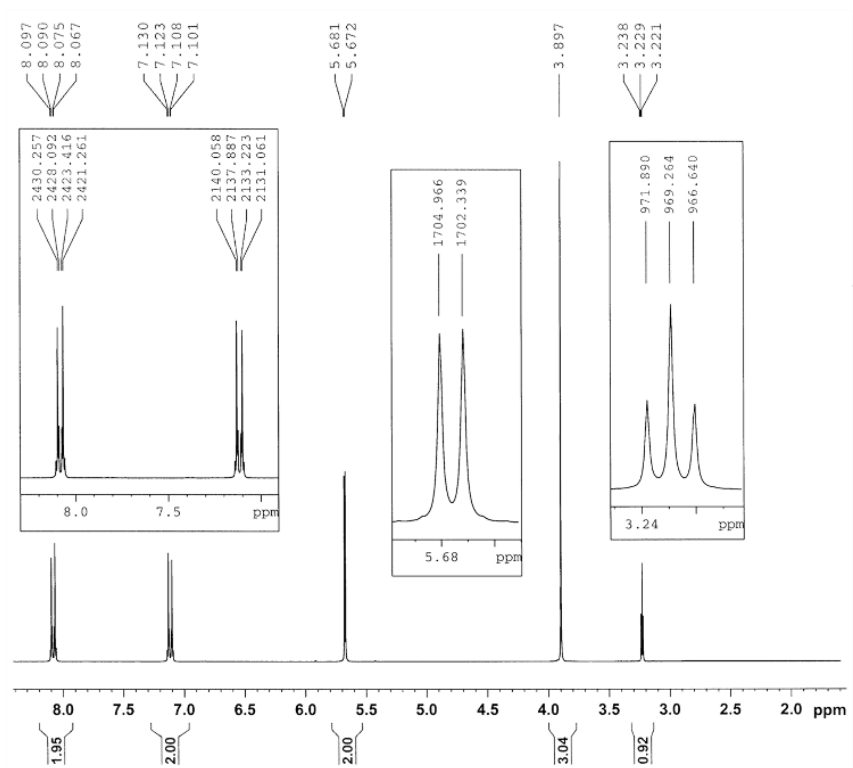

Fig. 5. ${ }^{1} \mathrm{H}-\mathrm{NMR}$ 1D spectrum of compound (3).

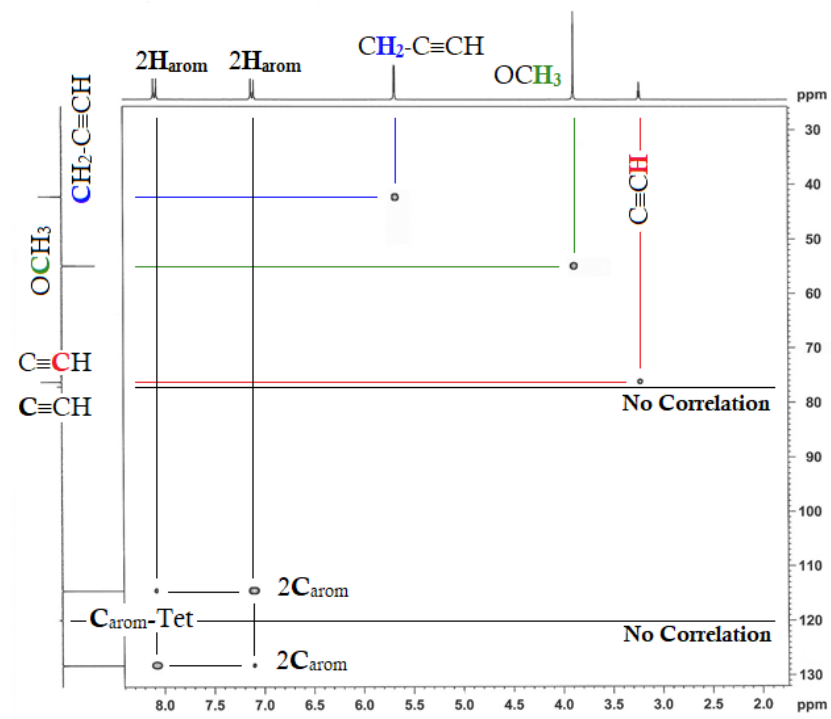

Fig. 6. 2D HSQC spectrum of compound (3).
The interpretation of its HSQC 2D NMR spectrum (Fig. 6) showed a perfect correlation, proton-carbon.

The last step (Scheme 8) in our strategy for the synthesis of the triheterocyclic compound, a precursor of the biheterocyclic $\alpha$-amino acid, derived from triazole and tetrazole (5), consisted of linking two molecules by an extremely stable triazole bond via a cycloaddition reaction [3+2] between an azide, 4-(azidomethyl)-4-ethyl-2-phenyl4,5-dihydrooxazole (4) and the terminal alkyne, 5-(4methoxyphenyl)-2-(prop-2-yn-1-yl)-2H-tetrazole (3).

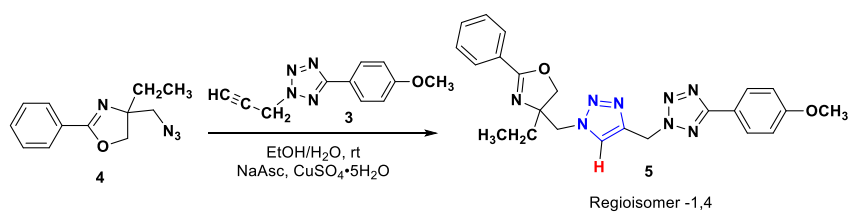

Scheme 8 . Key step in the synthesis of the tri-heterocyclic compound (5).

Thus, we adopted Huigsen's 1,3-dipolar cycloaddition reaction, catalyzed by copper (I) formed in situ by reduction of $\mathrm{Cu}(\mathrm{II})$ salts $\left(\mathrm{CuSO}_{4}, 5 \mathrm{H}_{2} \mathrm{O}\right)$ by sodium ascorbate. This reaction protocol, discovered in 2002 simultaneously by the SHARPLESS [21] and MELDAL [34] research groups, is considered to be the most efficient and most widely used "click" reaction to date. The $\mathrm{Cu}(\mathrm{I})$ catalysis allowed us, on the one hand, to carry out the cycloaddition at room temperature during a reaction time of only 8 hours, and on the other hand to selectively obtain the 1,4-disubstituted 1,2,3-triazole derivative (5) one of the two possible isomers, with a yield of $90 \%$ after chromatography on a silica gel column (ether/hexane: 1/2), and recrystallization in an ether/acetone mixture. Due to its simplicity of implementation, its efficiency and the absence of by-products, this reaction has rapidly become one of the most widely used reactions in all fields of chemical and biological sciences.

The identity of the new compound is proven beyond doubt by spectroscopic and analytical methods, namely 1D NMR $\left({ }^{1} \mathrm{H},{ }^{13} \mathrm{C}\right)$ (Fig. 7, 8 and 9), mass and elemental analysis.

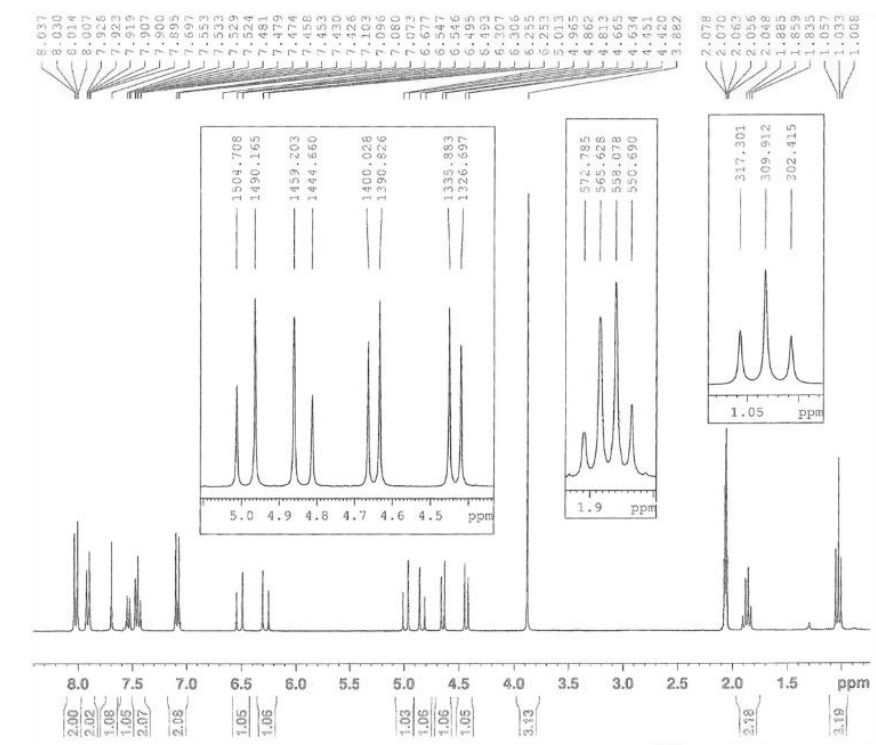

Fig. 7. ${ }^{1} \mathrm{H}-\mathrm{NMR} 1 \mathrm{D}$ spectrum of compound (5). 


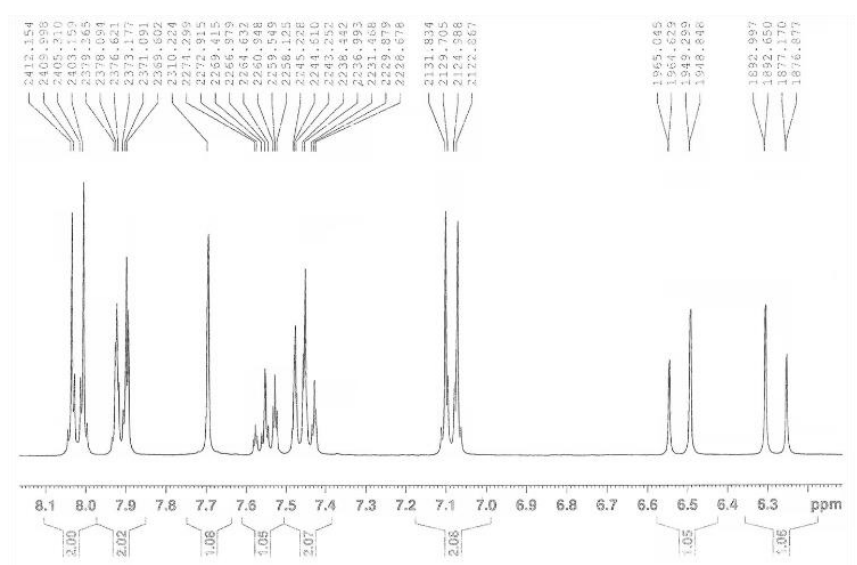

Fig. 8. Enlargement of the ${ }^{1} \mathrm{H}-\mathrm{NMR}$ spectrum of compound (5) between 6.2 ppm and $8.1 \mathrm{ppm}$.

Thus, its ${ }^{1} \mathrm{H}$ NMR spectra (Fig. 7 and 8) were characterized by the presence of the following signals:

- A triplet towards $1.03 \mathrm{ppm}$ corresponding to the 3 protons of methyl $-\mathrm{CH}_{3}(\mathrm{~J}=7.4 \mathrm{~Hz})$.

- A quadruplet towards $1.87 \mathrm{ppm}$ corresponding to the 2 protons of methylene $-\mathrm{CH}_{2}-\mathrm{CH}_{3}(\mathrm{~J}=7.4 \mathrm{~Hz})$.

- A singlet around $3.88 \mathrm{ppm}$ corresponding to the 3 protons of the methoxy group $-\mathrm{OCH}_{3}$.

- An AB system around 4.54 ppm corresponding to the 2 protons of methylene $-\mathrm{CH}_{2}-(\mathrm{Oxaz})(\mathrm{J}=9.3 \mathrm{~Hz})$.

- An AB system around $4.91 \mathrm{ppm}$ corresponding to the 2 protons of the methylene $-\mathrm{CH}_{2}$-Triaz $(J=14.7 \mathrm{~Hz})$.

- An AB system around 6.28 ppm corresponding to the 2 protons of methylene $-\mathrm{CH}_{2}$-Tetraz $(\mathrm{J}=0.3 \mathrm{~Hz})$.

- A doublet split around $7.08 \mathrm{ppm}$ corresponding to the 2 aromatic protons $\left(J_{1}=6.9 \mathrm{~Hz}\right.$ and $\left.J_{2}=2.1 \mathrm{~Hz}\right)$.

- A multiplet towards 7.43-7.55 ppm corresponding to the 3 aromatic protons of the benzene nucleus.

- A singlet around $7.7 \mathrm{ppm}$ corresponding to the proton of the triazole nucleus $=\mathrm{C}^{5}-\mathrm{H}$.

- A multiplet towards 7.89-7.92 ppm corresponding to the 2 aromatic protons of the benzene nucleus.

- A doublet split around $8.02 \mathrm{ppm}$ corresponding to the 2 aromatic protons $\left(J_{1}=6.9 \mathrm{~Hz}\right.$ and $\left.J_{2}=2.1 \mathrm{~Hz}\right)$.

Thus, contrary to the data in the literature [35], including the work carried out in our laboratory [36], the triazole proton $\mathrm{H}-5$ resonates at $7.7 \mathrm{ppm}$ and is therefore less deshielded. This inverse phenomenon can be justified by the fact that the $\mathrm{H}-5$ proton does not undergo the anisotropic effect of the tetrazole nucleus.

Its ${ }^{13} \mathrm{C}$ NMR spectrum (Fig. 9) has, among others, the following characteristic signals:

- A signal around $5.04 \mathrm{ppm}$ corresponding to methyl carbon $-\mathrm{CH}_{3}$.

- A signal around $30.17 \mathrm{ppm}$ corresponding to the carbon of the methylene $-\mathrm{CH}_{2}-\mathrm{CH}_{3}$.

- A signal around 45.36 ppm corresponding to the carbon of the methylene $-\mathrm{CH}_{2}$-Triaz.

- A signal around $54.51 \mathrm{ppm}$ corresponding to the carbon of the methylene $-\mathrm{CH}_{2}$-Tetraz.

- A signal around 54.88 ppm corresponding to the carbon of the methoxy group $-\mathrm{OCH}_{3}$.

- A signal around $72.37 \mathrm{ppm}$ corresponding to the quaternary carbon -Cq-(Oxaz).
- A signal around $72.78 \mathrm{ppm}$ corresponding to the carbon of the methylene $-\mathrm{CH}_{2}-(\mathrm{Oxaz})$.

- An intense signal around 114.38 ppm corresponding to the 2 aromatic carbons.

- A signal around $115.7 \mathrm{ppm}$ corresponding to the carbon $=\mathrm{C}^{5}-\mathrm{H}$ of the 1,2,3-traizole nucleus.

- An intense signal around 119.73 ppm corresponding to the quaternary aromatic carbon linked to the tetrazole.

- A signal around $127.14 \mathrm{ppm}$ corresponding to the carbon $=\mathrm{C}^{4}$ of the 1,2,3-traizole nucleus.

- An intense signal around 128.18 ppm corresponding to the two aromatic carbons.

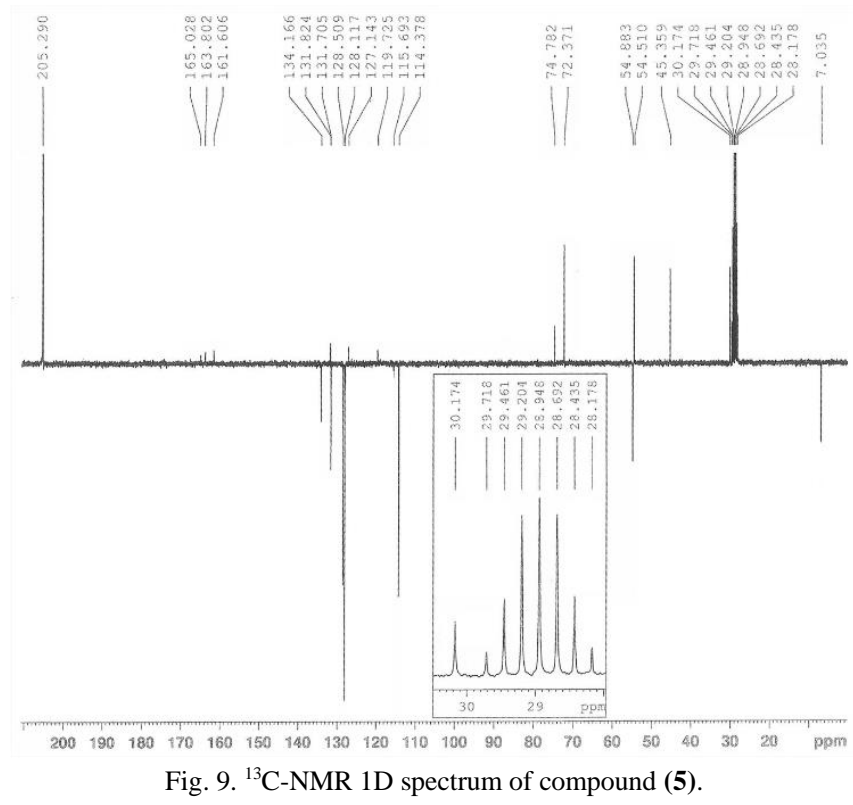

\section{MATERIALS AND METHODS}

All solvents were purified following the standard techniques and commercial reagents were purchased from Sigma-Aldrich (St. Louis, MO, USA). Melting point was determined with an electrothermal melting point apparatus and was uncorrected. NMR spectra $\left({ }^{1} \mathrm{H}\right.$ and $\left.{ }^{13} \mathrm{C}\right)$ were recorded on a Bruker AM 300 spectrometer (operating at $300.13 \mathrm{MHz}$ for ${ }^{1} \mathrm{H}$, at $75.47 \mathrm{MHz}$ for ${ }^{13} \mathrm{C}$ ) (Bruker Analytische Messtechnik GmbH, Rheinstetten, Germany). NMR data are listed in $\mathrm{ppm}$ and are reported relative to tetramethylsilane $\left({ }^{1} \mathrm{H},{ }^{13} \mathrm{C}\right)$; residual solvent peaks being used as an internal standard. All reactions were followed by thinlayer chromatography (TLC). TLC analyses were carried out on $0.25 \mathrm{~mm}$ thick pre-coated silica gel plates (Merck Fertigplatten Kieselgel $60 \mathrm{~F}_{254}$ ) and spots were visualized under UV light or by exposure to vaporized iodine. Mass spectra were measured on a JEOL-JMS-DX 300 FAB instrument and Desorption in chemical ionisation with $\mathrm{NH}_{3}$ DCI instrument. Elemental analysis was performed with a Flash 2000 EA 1112, Thermo Fisher Scien-tific-Elemental Analyzer (CNRST-Rabat, Morocco).

4-methoxybenzaldehyde oxime (1)

To 35 mmoles of sodium hydroxide $(\mathrm{NaOH})$ and 20 mmoles of aldehyde in $4 \mathrm{~mL}$ of water, 22 mmoles of hydroxylamine hydrochloride were added in small portions. The mixture was kept stirred at room temperature for 4 hours. After reaction, the solution was filtered and the rest of the 
oxime in the aqueous phase was extracted with ether. The resulting solution was dried and then evaporated. The resulting solid was recrystallized in an ether/petroleum ether mixture.

Yield $=90 \%($ White solid $) ; \mathrm{R}_{\mathrm{f}}=0.35 \mathrm{AcOEt} /$ hexane $(1 / 4)$; m.p. $=52^{\circ} \mathrm{C}$.

${ }^{1} \mathrm{H}-\mathrm{NMR}\left(\mathrm{CDCl}_{3}, \mathrm{ppm}\right): 3.84\left(3 \mathrm{H}, \mathrm{s},-\mathrm{OCH}_{3}\right) ; 6.93(2 \mathrm{H}, \mathrm{dd}$, $\left.J_{1}=6.9 \mathrm{~Hz}, J_{2}=2.1 \mathrm{~Hz}, 2 \mathrm{H}_{\text {arom }}\right) ; 7.55\left(2 \mathrm{H}, \mathrm{dd}, J_{1}=6.9 \mathrm{~Hz}\right.$, $\left.J_{2}=2.1 \mathrm{~Hz}, 2 \mathrm{H}_{\text {arom }}\right) ; 8.17(1 \mathrm{H}, \mathrm{s},-\mathrm{CH}=\mathrm{N}-) ; 9.42(1 \mathrm{H}, \mathrm{e},-\mathrm{OH})$. ${ }^{13} \mathrm{C}-\mathrm{NMR}\left(\mathrm{CDCl}_{3}, \mathrm{ppm}\right): 55.35\left(-\mathrm{OCH}_{3}\right) ; 114.31\left(2 \mathrm{C}_{\mathrm{arom}}-\mathrm{H}\right)$; $\left.124.56\left(1 \mathrm{C}_{\text {arom }}-\mathrm{CH}=\mathrm{N}\right) ; 128.632 \mathrm{C}_{\text {arom }}-\mathrm{H}\right) ; 150.03(-\mathrm{CH}=\mathrm{N}-$ $\mathrm{OH}) ; 161.10\left(1 \mathrm{C}_{\text {arom }}-\mathrm{O}\right)$.

5-(4-methoxyphenyl)-1H-tetrazole (2)

10 mmoles of 4-methoxybenzaldehyde oxime and 10 mmoles of paratoluenesulfonic acid monohydrate in $12 \mathrm{~mL}$ of $\mathrm{N}, \mathrm{N}$-dimethylformamide (DMF) are stirred with $0.65 \mathrm{~g}$ (10 mmoles) of $\mathrm{NaN}_{3}$. After reaction water was added to the reaction residue, the aqueous phase was extracted three times with methylene chloride or ether and then acidified with a solution of $3 \mathrm{M}$ hydrochloric acid. The precipitated tetrazole was filtered, the rest of the product in the aqueous phase was extracted with ethyl acetate, the organic phase was dried on $\mathrm{Na}_{2} \mathrm{SO}_{4}$ and then evaporated to dryness. The solid obtained was added to the precipitate and then the whole was recrystallized in ethanol.

Yield $=75 \%$ (White solid $) ;$ m.p. $=235^{\circ} \mathrm{C}$.

${ }^{1} \mathrm{H}-\mathrm{NMR}$ (DMSO-d 6 , ppm): $3.83\left(3 \mathrm{H}, \mathrm{s},-\mathrm{OCH}_{3}\right) ; 7.14(2 \mathrm{H}$, $\left.\mathrm{d}, J=8.8 \mathrm{~Hz}, 2 \mathrm{H}_{\text {arom }}\right) ; 7.98\left(2 \mathrm{H}, \mathrm{d}, J=8.8 \mathrm{~Hz}, 2 \mathrm{H}_{\text {arom }}\right)$.

${ }^{13} \mathrm{C}-\mathrm{NMR}$ (DMSO-d 6 ), ppm): $55.87\left(-\mathrm{OCH}_{3}\right) ; 115.27\left(2 \mathrm{C}_{\mathrm{arom}^{-}}\right.$ $\mathrm{H})$; 116.73 (1C $\mathrm{Carom}$-Tetraz); $129.08\left(2 \mathrm{C}_{\text {arom }}-\mathrm{H}\right) ; 150.03$ (1Cq(Tetraz)); 161.91 ( $\left.1 \mathrm{C}_{\text {arom }}-\mathrm{O}\right)$.

5-(4-methoxyphenyl)-2-(prop-2-yn-1-yl)-2H-tetrazole (3)

To 10 mmoles of 5-(4-methoxyphenyl)- $1 H$-tetrazole suspended in $10 \mathrm{~mL}$ of acetonitrile, 11 mmoles of triethylamine and 4 mmoles of 18 -crown- 6 ether were added. Propargyl bromide (10 mmoles) was then added and the reaction mixture was stirred at room temperature for 4 hours. After reaction, the solution was filtered, the solvent was evaporated and the residue obtained is chromatographed on a silica gel (hexane ether) column. The solid obtained was recrystallized in a petroleum ether/methylene chloride mixture.

Yield $=82 \%$, m.p. $=71^{\circ} \mathrm{C}, \mathrm{Rf}=0.73$ (ether/petroleum ether: $2 / 1)$

${ }^{1} \mathrm{H}-\mathrm{NMR}$ (acetone- $\left.\mathrm{d}_{6}, \mathrm{ppm}\right): 3.23(1 \mathrm{H}, \mathrm{t}, J=2.62 \mathrm{~Hz},-\mathrm{C}$ $\equiv \mathrm{CH}) ; 3.89\left(3 \mathrm{H}, \mathrm{s},-\mathrm{OCH}_{3}\right) ; 5.68\left(2 \mathrm{H}, \mathrm{d}, J=2.62 \mathrm{~Hz},-\mathrm{CH}_{2}-\right.$ $\mathrm{C} \equiv \mathrm{CH}) ; 7.11\left(2 \mathrm{H}, \mathrm{dd}, \mathrm{J}_{1}=6.8 \mathrm{~Hz}, J_{2}=2.2 \mathrm{~Hz}, 2 \mathrm{H}_{\text {arom }}\right) ; 8.08$ $\left(2 \mathrm{H}, \mathrm{dd}, J_{1}=6.8 \mathrm{~Hz}, J_{2}=2.2 \mathrm{~Hz}, 2 \mathrm{H}_{\text {arom }}\right)$.

MS $\left[\mathrm{DCI} / \mathrm{NH}_{3}\right]:[\mathrm{M}+\mathrm{H}]^{+}=215$ and $\left[\mathrm{M}+\mathrm{NH}_{4}\right]^{+}=232$.

Anal. Calcd. for $\mathrm{C}_{11} \mathrm{H}_{10} \mathrm{~N}_{4} \mathrm{O}(\%)$ : C, 61.67; H, 4.71; N, 26.15; Found (\%): C, 61.64; H, 4.75; N, 26.19.

4-ethyl-4-((4-((5-(4-methoxyphenyl)-2H-tetrazol-2-yl) methyl)-1H-1,2,3-triazol-1-yl)methyl)-2-phenyl-4,5dihydrooxazole (5)

2.2 mmoles of alkyne (3) and 2.2 mmoles of oxazoline azide (4) were stirred in $10 \mathrm{~mL}$ of an ethanol-water mixture $(1 / 1), 0.05$ equivalent of copper sulphate pentahydrate $\left(\mathrm{CuSO}_{4}, 5 \mathrm{H}_{2} \mathrm{O}\right)$ and 0.1 equivalent of sodium ascorbate $(\mathrm{Na}-$ Asc) were added. The TLC analysis indicated complete consumption of the reactants after 8 hours of stirring at room temperature. After filtration of the precipitate formed, the solvent was evaporated under pressure and the crude was washed with water and extracted with methylene chloride. The organic phase is then dried with magnesium sulphate and the solvent was removed under reduced pressure. The oil obtained was purified by chromatography on a silica gel column (ether/hexane: 1/2). The solid obtained was recrystallized in an ether/acetone mixture.

Yield $=90 \%$ (White solid); $\mathrm{R}_{\mathrm{f}}=0.4$ (ether/acetone 5\%); m.p. $=160^{\circ} \mathrm{C}$.

${ }^{1} \mathrm{H}-\mathrm{NMR}$ (Acetone-d $\left.\mathrm{d}_{6}, \delta \mathrm{ppm}\right): 1.03(3 \mathrm{H}, \mathrm{t}, J=7.4 \mathrm{~Hz}$, $\left.\mathrm{CH}_{3}\right) ; 1.87\left(2 \mathrm{H}, \mathrm{q}, J=7.4 \mathrm{~Hz},-\mathrm{CH}_{2}-\mathrm{CH}_{3}\right) ; 3.88(3 \mathrm{H}, \mathrm{s}$, $\left.\mathrm{OCH}_{3}\right) ; 4.54\left(2 \mathrm{H}, \mathrm{AB}, J=9.3 \mathrm{~Hz},-\mathrm{CH}_{2}-(\mathrm{Oxaz})\right) ; 4.91(2 \mathrm{H}$, $\mathrm{AB}, J=14.7 \mathrm{~Hz},-\mathrm{CH}_{2}$-Triaz); $6.28(2 \mathrm{H}, \mathrm{AB}, J=0.3 \mathrm{~Hz}$, $\mathrm{CH}_{2}$-Tetraz); $7.08\left(2 \mathrm{H}, \mathrm{dd}, J_{1}=6.9 \mathrm{~Hz}, J_{2}=2.1 \mathrm{~Hz}, 2 \mathrm{H}_{\text {arom }}\right)$; 7.43-7.55 (3H, m, 3H $\left.\mathrm{H}_{\text {arom }}\right)$; $7.7\left(1 \mathrm{H}, \mathrm{s},=\mathrm{C}^{5}-\mathrm{H}\right) ; 7.89-7.92(2 \mathrm{H}$, $\left.\mathrm{m}, 2 \mathrm{H}_{\text {arom }}\right) ; 8.02\left(2 \mathrm{H}, \mathrm{dd}, J_{1}=6.9 \mathrm{~Hz}, J_{2}=2.1 \mathrm{~Hz}, 2 \mathrm{H}_{\text {arom }}\right)$.

${ }^{13} \mathrm{C}-\mathrm{NMR}$ (Acetone- $\left.\mathrm{d}_{6}, \delta \mathrm{ppm}\right): 5.04\left(-\mathrm{CH}_{3}\right) ; 30.17\left(-\mathrm{CH}_{2}-\right.$ $\mathrm{CH}_{3} 45.36 \quad\left(-\mathrm{CH}_{2}\right.$-Triaz); $54.51 \quad\left(-\mathrm{CH}_{2}\right.$-Tetraz); 54.88 $\left.\mathrm{OCH}_{3}\right) ; 72.37$ (-Cq-(Oxaz)); 72.78 (-CH $\left.2-(\mathrm{Oxaz})\right) ; 114.38$ $\left(2 \mathrm{C}_{\text {arom }}-\mathrm{H}\right) ; 115.7$ (=C 5 -H(Triaz)); 119.73 (1 $\mathrm{C}_{\text {arom }}-$ Tetraz $)$; $127.14\left(=\mathrm{C}^{4}(\right.$ Triaz $\left.)\right) ; 128.18\left(2 \mathrm{C}_{\text {arom }}-\mathrm{H}\right) ; 128.51\left(2 \mathrm{C}_{\mathrm{arom}}-\mathrm{H}\right)$; $131.70\left(1 \mathrm{C}_{\text {arom}}-\mathrm{Oxaz}\right) ; 131.82\left(2 \mathrm{C}_{\text {arom }}-\mathrm{H}\right) ; 134.17\left(2 \mathrm{C}_{\text {arom }}-\mathrm{H}\right)$; $161.61 \quad(-\mathrm{C}=\mathrm{N}(\mathrm{Oxaz})) ; \quad 163.8 \quad\left(1 \mathrm{C}_{\text {arom }}-\mathrm{O}\right) ; \quad 165.03$ $\left(=\mathrm{C}^{5}(\right.$ Tetraz $\left.)\right)$.

MS [DCI/NH 3$]:[\mathrm{M}+\mathrm{H}]^{+}=445$.

Anal. Calcd. for $\mathrm{C}_{23} \mathrm{H}_{24} \mathrm{~N}_{8} \mathrm{O}_{2}(\%)$ : C, 62.15; H, 5.44; N, 25.21; Found (\%): C, 62.18; H, 5.41; N, 25.24.

\section{CONCLUSION}

In summary, the 1,3-dipolar cycloaddition reaction between azide (4) and heterocyclic (3) terminal alkyne, catalyzed by copper (I), provided regioselective access to the 1,4-regioisomer (5) with an excellent yield. The structural characterization was determined by Proton nuclear magnetic resonance ( $\left.{ }^{1} \mathrm{H}-\mathrm{NMR}\right), \quad$ Carbon-13 nuclear magnetic resonance $\left({ }^{13} \mathrm{C}-\mathrm{NMR}\right)$, mass spectrometry, and elemental analysis. The chemical shift of the triazole proton $\mathrm{H}-5$, which resonates at $7.7 \mathrm{ppm}$ can be justified by the fact that the $\mathrm{H}-5$ proton does not undergo the anisotropic effect of the tetrazolic cycle. The evaluation of the anti-corrosion and biological activities of the synthesized product is under way.

\section{ACKNOWLEDGMENT}

This work was supported by Sidi Mohammed Ben Abdellah University (USMBA) and National Center for Scientific and Technical Research (CNRST).

\section{REFERENCES}

[1] Zhang, J. Wang, S. Ba, Y. Xu, Z. Tetrazole hybrids with potential anticancer activity. European Journal of Medicinal Chemistry, 1996, 178, pp. 341-351. https://doi.org/10.1016/j.ejmech.2019.05.071.

[2] Wang, S. Q., Wang, Y. F. and Xu, Z. (2019). Tetrazole hybrids and their antifungal activities. European Journal of Medicinal Chemistry. 2019, 170, pp. 225-234. https://doi.org/10.1016/j.ejmech.2019.03.023

[3] Vidya S. D., Aniket P. S., Shailee V. T., Deepak K. L., Kshipra S. K. Ishwari A. K., Suneel D. Sunil S. J., Prasad V.L.S.B. Ultrasound assisted synthesis of tetrazole based pyrazolines and isoxazolines as potent anticancer agents via inhibition of tubulin polymerization. 
Bioorganic \& Medicinal Chemistry Letters, 2020, 30, 127592. .https://doi.org/10.1016/j.bmcl.2020.127592.

[4] Roh, J. Karabanovich, G. Vlčková, H. Carazo, A. Němeček, J. Sychra, P.1 Valášková, L. Pavliš, O. Stolaříková, J. Klimešová, V. Vávrová, K. Pávek, P. Hrabálek, A. Development of water-soluble 3,5 dinitrophenyl tetrazole and oxadiazole antitubercular agents. Bioorganic and Medicinal Chemistry, 2017, 25(20), pp. 5468-5476. http://dx.doi.org/10.1016/j.bmc.2017.08.010

[5] Gao, C. Chang, L. Xu, Z. Yan, X. Ding, C. Zhao, F. Wu, X. Feng, L. Recent advances of tetrazole derivatives as potential anti-tubercular and anti-malarial agents. European Journal of Medicinal Chemistry, 2019, 163, pp. 404-412. https://doi.org/10.1016/j.ejmech.2018.12.001.

[6] Zhan, P. Li, Z. Liu, X. Clercq, D.E. Sulfanyltriazole/tetrazoles: A Promising Class of HIV-1 NNRTIs. Mini-Reviews in Medicinal Chemistry. 2012, 9(8), pp. 1014-1023. https://doi.org/10.2174/138955709788681618.

[7] Verma, C., Quraishi, M. A. and Singh, A. 5-Substituted 1H-tetrazoles as effective corrosion inhibitors for mild steel in $1 \mathrm{M}$ hydrochloric acid. Journal of Taibah University for Science, 2016, 10(5), pp. 718-733. https://doi.org/10.1016/j.jtusci.2015.10.005.

[8] Aouine, Y. Sfaira, M. Ebn Touhami, M. Alami, A. Hammouti, B. Elbakri, M. El Hallaoui, A. Touir, R. Temperature and time investigations on the adsorption behavior of isoindoline, tetrazole and isoindoline-tetrazole on corrosion of mild steel in acidic medium International Journal of Electrochemical Science, 2012, 7(6), pp. 5400-5419.

[9] Elkacimi, Y. Achnin, M. Aouine, Y. Ebn Touhami, M. Alami, A. Touir, R. Sfaira, M. Chebabe, D. Elachqar, A. Hammouti, B. Inhibition of mild steel corrosion by some phenyltetrazole substituted compounds in hydrochloric acid. Portugaliae Electrochimica Acta, 2011, 30(1), pp. 53-65. https://doi.org/10.4152/pea.201201053.

[10] Herr, R. J. 5-Substituted-1H-tetrazoles as carboxylic acid isosteres: Medicinal chemistry and synthetic methods. Bioorganic and Medicinal Chemistry, 2002, 10(11), pp. 3379-3393. https://doi.org/10.1016/S0968-0896(02)00239-0.

[11] Maybridge MedChem. Bioisosteres in Medicinal Chemistry, 2004, 1, 1

[12] Duncia, J. V. CHIU, A. T. CARINI, D. J. GREGORY, G. B. The Discovery of Potent Nonpeptide Angiotensin II Receptor Antagonists: A New Class of Potent Antihypertensives. Journal of Medicinal Chemistry, 1990, 33(5), pp. 1312-1329. https://doi.org/10.1021/jm00167a007.

[13] Katritzky, A. R., Cai, C. and Meher, N. K. Efficient synthesis of 1,5disubstituted tetrazoles. Synthesis, 2007, 8, pp. 1204-1208 https://doi.org/0.1055/s-2007-966001.

[14] Demko, Z. P. and Sharpless, K. B. Jo010635W-2. 2001, 6, pp. 7945 7950. https://doi.org/10.1021/jo010635w.

[15] Alami, A., El Hallaoui, A., El Achqar, A., Roumestant, M. L., Viallefont, Ph. The use of 5-substituted tetrazoles in a Synthesis of heterocyclic $\alpha$-amino esters. Bull. Soc. Chim. Belg., 1996, 105 (12), 769.

[16] Alami, A., El Hallaoui, A., El Achqar, A., El Hajji, S., Roumestant, M. L., Viallefont, Ph. Synthesis of $\beta$-Tetrazolyl DL-Alanine Derivatives. Preparative Biochemistry and Biotechnology, 1998, 28 :2, 167-173. http://dx.doi.org/10.1080/10826069808010133.

[17] Achamlale, A. Elachqar, A. El Hallaoui, A. Alami, S. El Hajji, M. L. Roumestant, Viallefont, $\mathrm{Ph}$. Synthesis of biheterocyclic $\alpha$-amino acids, $\begin{array}{llll}\text { Amino } & \text { Acids, } & 1999, & 149,\end{array}$ http://dx.doi.org/10.1080/10826069808010133.

[18] Aouine, Y., Aarab N., Alami, A., El Hallaoui, A., Ebn Touhami, M., Elachqar, A., Sfaira, M., Faraj, H. Synthesis and Characterization of novel 5-substituted tetrazoles having an inhibiting activity of corrosion for mild steel in the acidic media. Moroccan Journal of Heterocyclic

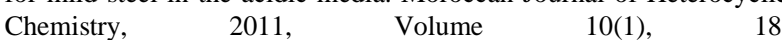
https://doi.org/10.48369/IMIST.PRSM/jmch-v10i1.2908.

[19] El Hajji, S., Ph.D. Thesis, Sidi Mohamed Ben Abdellah University, Fez, MA, 1992.

[20] Zaid, F., Thesis, Sidi Mohamed Ben Abdellah University, Fez. MA, 1996.

[21] Rostovtsev, V. V., Green, L. G., Fokin, V. V. and Sharpless, K. B. A Stepwise Huisgen Cycloaddition Process: Copper(I)-Catalyzed Regioselective "Ligation" of Azides and Terminal Alkynes. Angew. Chemie. Int. Ed. 2002, 41 (14), 2596-2599. https://doi.org/10.1002/1521-3773(20020715)41:14<2596::AIDANIE2596>3.0.CO;2-4.

[22] A. Atmani, A. El Hallaoui, S. El Hajji, M. L. Roumestant, P. Viallefont. From oxazolines to precursors of amino acids. Synth. Commun., vol. 21, pp. 2383-2390, 1991

[23] Hajib, S. Ksakas, A. Aouine, Y. Alami, A. and Faraj, H. Synthesis and Structural Determination of Two New tri-Heterocyclic Regioisomeric Compounds, Precursors of Bi-Triazolic $\alpha$-Amino Acids, via a
Comparative Study using 1D NMR Spectroscopy. European Journal of Advanced Chemistry Research, 2020, 1(6), pp. 2-7. https://doi.org/10.24018/ejchem.2020.1.6.36.

[24] Lippmann, E., Könnecke, A., Z. Chem, 16, 90 (1976).

[25] F. R. Benson, F.R. Heterocyclic compounds; Vol 8, ed. Wiley (1967).

[26] Janda, U., Votický, Z., Jakubcová, J., Světlík, J., Grimová, J. Maturová, E. Semisynthetic cephalosporines. Synthesis of some substituted tetrazolyl acetic and propionic acids. Collect. Czech. Chem. Commun. 1984, 49, 1699-1712. https://doi.org/10.1135/cccc19841699.

[27] Padwa, A., Nahm, S. and Sato, E. Photochemical transformations of small ring heterocyclic compounds. 9. Intramolecular 1,3-dipolar cycloaddition reactions of alkenyl-subituted nitrile imines. Journal of Organic Chemistry, 1978, 43(9), pp. 1664-1671. https://doi.org/10.1021/jo00403a009.

[28] Kishore V, Parmar SS, Gildersleeve DL. Synthesis of 2,5-disubstituted tetrazoles as possible antiinflammatory agents. J. Heterocycl. Chem., $1978,15,1335-1338$.

[29] Peet, N.P. and Sunder, S., J. Heterocycl. Chem. 1977, vol. 14, p. 561.

[30] Vereshchagin, L.I., Buzilova, S.R., Mityukova, T.K., Proidakov, A.G., Kizhnyaev, V.N., Il'ina, V.V., Sukhanov, G.T., Gareev, G.A., Bogens, A.K., Zh. Org. Khim; 22, 1979-1783 (1986).

[31] Elguero, J., Marzin, C. and Roberts, J. D. (1974) 'Carbon-13 Magnetic Resonance Studies of Azoles. Tautomerism, Shift Reagent Effects, and Solvent Effects', Journal of Organic Chemistry, 39(3), pp. 357-363. https://doi.org/10.1021/jo00917a017.

[32] Taurins, A. and Viron, S. J. (1953) 'the Tautomerism of 2Nitraminopyridines', Canadian Journal of Chemistry, 31(11), pp. 1048-1053. https://doi.org/10.1039/P29890001903.

[33] Butler, R. N. and Fitzgerald, K. J. (1988) 'Reaction of benzonitrile N(p-nitrophenyl) imide with 5-substituted tetrazoles: A new route to substituted 1,2,4-triazoles via N- hydrazonoyltetrazoles', Journal of the Chemical Society, Perkin Transactions 1, (6), pp. 1587-1591. https://doi.org/10.1039/p19880001587.

[34] Tornøe, C. W., Christensen, C. and Meldal, M. Peptidotriazoles on solid phase: [1,2,3]-Triazoles by regiospecific copper(I)-catalyzed 1,3dipolar cycloadditions of terminal alkynes to azides. Journal of Organic Chemistry, 2002, 67(9), pp. 3057-3064. https://doi.org/10.1021/jo011148j.

[35] Tsypin, G. I., Timofeeva, T. N., Mel'nikov, V. V., Gidaspov, B. V., Zh. Khim Org. 1977, 13, 2281.

[36] Aouine Y., Thesis, Sidi Mohamed Ben Abdellah University, Fez, MA, 2015.

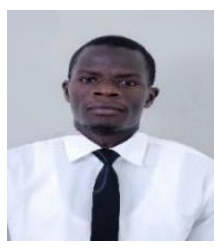

Khadim Dioukhane was born in Senegal where he obtained his baccalaureate degree in 2010 before coming to Morocco for university studies. He obtained his License in "Technology Food" at the Faculty of Sciences and Technologies of Sultan Moulay Slimane University of Béni Mellal, Morocco, in 2013. He obtained his Master degree in Structural Chemistry from the Faculty of Sciences of Sidi Mohamed Ben Abdellah University in Fez, Morocco, in 2015. Currently, he is pursuing for his doctoral studies in organic chemistry at the same faculty, where he focused on the synthesis, characterization, electrochemical and biological studies of certain mono and biheterocyclic compounds.

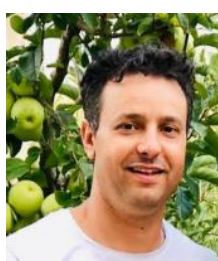

Aouine Younas was born in Aït-Seghrouchen of Taza, Morocco, in 1979. He received his higher education diploma in Chemistry from the Sidi Mohamed Ben Abdellah University of Fez, Morocco, in 2003. He obtained his advanced degree (D.E.S.A) and Ph.D. degree in Organic and Heterocyclic Chemistry from the same university, in 2005 and 2015, respectively.

Since 2006, he has been working as a researcher in organic chemistry laboratory (LCO) at the Faculty of Sciences DM, University of Fez. In 2008, he joined the Ministry of Education as a professor of Physical Sciences and Chemistry in Imzouren High School, Al Hoceima in northern Morocco.

Since 2018, he joined the Department of Chemistry of the Ibn Zohr University, Agadir, as an assistant professor. His teaching has been devoted to organic and heterocyclic chemistry courses. His current research is focalized firstly on synthesis and characterization of new heterocyclic $\alpha$-amino acids and their precursors and on the other hand on the study of their biological and electrochemical activities. He has published the results of research ( +70 publications and communications) in several national and international journals.

Scopus Author ID: 35742904200. 


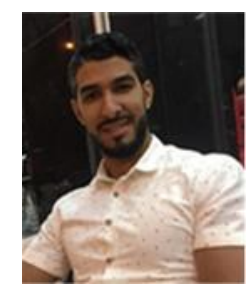

Salaheddine Boukhssas was born in Fez, Morocco, in 1992. He received his higher education degree in Chemistry and a Master's Degree in Organic Chemistry from the Sidi Mohamed Ben Abdellah University, Faculty of Sciences DM of Fez, Morocco, respectively in 2014 and 2016. Then, he obtained a Ph.D. degree in the field of heterocyclic chemistry in the organic chemistry laboratory and he began his career as an assistant teacher in the same Faculty. Presently he is engaged in the field of education as a professor of Physical Sciences and Chemistry at Jbabra High school in Taounate City, Morocco.

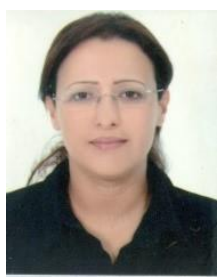

Asmae Nakkabi chemist, she obtained his master in Molecular Chemistry and Natural Substances in Faculty of Sciences, Meknes University Moulay Ismail in 2011, the $\mathrm{PhD}$ degree in chemistry specialty "Environmental Chemistry" in 2016 from the same university.

She is currently a searcher in Laboratory of Chemistry of Materials and Biotechnology natural products.

She has published the results of research $(+40$ publications and communications) in several international journals.

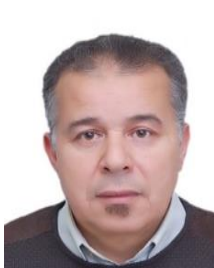

Faraj Hassane was born in Fez, Morocco, in 1963. He studied Chemistry at Montpellier II University, France and he obtained his Ph.D. degree in 1991.

$\mathrm{He}$ then joined the department of chemistry at the Faculty of Sciences Dhar El Marhaz, Sidi Mohamed Ben Abdellah University (Fez, Morocco) in 1993.

His current research is focused on the synthesis and characterization of new heterocyclic $\alpha$-amino acids and their precursors and on the other hand on the study of their biological and electrochemical activities. He has taken part in conferences and communications in national and international congresses and has published the results of research (+70 publications and communications) in several international journals.

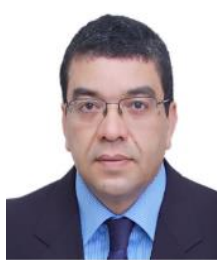

Alami Anouar was born in Fez, Morocco, in 1966.

He studied Chemistry at Montpellier II University, France and he obtained his Ph.D. degree in 1991.

He then joined the Department of Chemistry at the FSDM, USMBA Fez, Morocco in 1992. He prepared his state doctorate thesis degree in Organic Chemistry in 1997 at USMBA.

Among the responsibilities he assumed: Head of Department of Chemistry, elected for two terms 2013-2015 and 2016-2017 of the Council of FSDM, Chairman of the TRANSMEDITERRANEAN COLLOQUIUM ON HETEROCYCLIC CHEMISTRY, November 22-25, 2017, Fez, Morocco, http://tramech9.raidghost.com/, Responsible for the doctoral training "Bioactive Molecules, Health and Biotechnologies", 2014-2018, Director of the Laboratory of organic chemistry, 2014-2018, Coordinator of the Bachelor's degree program "Chemistry Sciences", FSDM, 2005-2012, Project Manager "President of the Coordination Commission with higher education, from the Board of the Academy of Fez-Boulemane Region, 2009-2012, Elected Member of the Council of USMBA, Fez, 2009-2011, Elected member of the Management Board USMBA, Fez 2011, Chairman of the International Symposium on heterocyclic chemistry, October 26-29, 2011. http://ishc2011.6te.net/Sitefr/index.html, Elected member of the college of the chemistry department, 2000-2012.

He strongly believes in the cognitive complementarity of science and in parallel to all his responsibilities, he had prepared a DEUG (2008) and a License (2010) in Private Law in French and a Master in Economics and Management (2013) at the Faculty of Economics, Law, and Social Sciences of Fez. Concerning the scientific research side. He had published more than 130 research articles indexed in several databases (Scopus, Web of science, Elsevier, Eric, IMIST...) till 2019, in various fields: Heterocyclic chemistry, molecular biology, science education, applied research in pedagogy, Educational Technology).

Scopus Author ID: 6603718514

Web of Science ResearcherID: T-6219-2019. 